\title{
Effect of plasma grafting with Hexamethyldisiloxane on comfort and flame resistance of cotton fabric \\ DOI: 10.35530/IT.072.02.1842
}

\section{ABSTRACT - REZUMAT}

\section{Effect of plasma grafting with Hexamethyldisiloxane on comfort and flame resistance of cotton fabric}

We investigated the potential of atmospheric plasma technology to enhance the properties of textile material against flame propagation before and after washing. The effects of this treatment on the rigidification of the media were also determined using draping and bending stiffness tests. We showed that deposing Silicone molecules on cotton fabrics leads to flame retardant cotton with a conservation of the whole structure after burning. Moreover, washing of the sample evidenced high permanency of the thin grafted coating against chemical domestic washing detergent. Nevertheless, comfort properties of the textile decrease, which limits the applications of the plasma eco-friendly technology in the clothing industry.

Keywords: plasma activation, Siloxane, comfort, flame resistance

Influența grefării cu plasmă de hexametildisiloxan asupra confortului și rezistenței la flacără ale materialelor textile din bumbac

A fost investigat potențialul tehnologiei cu plasmă la presiune atmosferică de a spori proprietățile materialului textil împotriva propagării flăcării înainte și după spălare. Influența acestui tratament asupra rigidizării mediilor a fost determinată prin teste de rigiditate la îndoire și drapaj. S-a demonstrat că depunerea moleculelor de silicon pe materialele textile din bumbac conduce la ignifugare, prin conservarea întregii structuri după ardere. Mai mult, spălarea probei a evidențiat o permanență ridicată a stratului subțire grefat la detergentul chimic de spălat pentru uz casnic. Cu toate acestea, proprietățile de confort ale materialelor textile se diminuează, ceea ce limitează aplicațiile tehnologiei ecologice cu plasmă în industria confecțiilor.

Cuvinte-cheie: activare cu plasmă, Siloxan, confort, rezistență la flacără

\section{INTRODUCTION}

Worldwide demand for functional fibrous materials has increased significantly in recent years [1]. This increase is evidently accompanied with technical quality and environmental requirements [2]. This is particularly true in the field of protective textile, particularly for those facing the risk of fire since the standards and regulations on the fire resistance of textiles have been extended to a large number of sectors such as building, children's nightwear, transport, house equipment and gas barrier [3, 4]. At present, many chemical treatments make it possible to obtain textiles with flame-retardant properties [5], but these processes present some disadvantages as they are generally not eco-friendly [6]. In fact, the conventional processes either need a great consumption of energy and water or impose the use of chemical toxic compounds. Moreover, the final flame resistant material presents a significant change in its properties like a loss of its flexibility which make it less soft and not comfortable in wearing. Furthermore, the treatments are not resistant to washing and the textile becomes flammable after few domestic washing cycles. For these reasons, industries are continuously looking for new techniques and chemical products which are respectful of environmental safety guidelines and presents acceptable efficiency of ignition. Processes based on padding techniques with eco-friendly chemistry like phosphor and Siloxane are being tested [7-9].

In recent years, plasma technologies have been involved in several industrial processes in materials, finishing and functionalization [4, 10]. These technologies offer the advantage to be low energy consumer, soft enough when applied to different materials and to have low environmental impact. In the textile field, plasma activation was found to be an efficient technique for the modification of natural and synthetic textile materials. Indeed, it has been successfully applied to enhance dyeability of various fibres [11]. In addition, it was able to replace several wet finishing processes. The plasma finishing applications are realized through surface activation, ablation, etching, cross-linking, functionalization, film deposition or by a combination of these effects [12]. Nowadays, a great attention is paid to the development of flame retardant textiles using plasma activation for better attachment of chemicals. An important 
number of reports were published detailing the use of plasma to enhance finishing products attachment. In this context, atmospheric plasma technology has assumed a great attention since it is a dry and environmental method to achieve surface modification $[13,14]$. Atmospheric plasma has been used as it could be integrated within an already established continuous process. Therefore, this eco-friendly technology will not induce significant decrease of the productivity that makes it acceptable by industries in an economic point of view. In this paper, we investigate the effect of a silicone coating applied with atmospheric pressure plasma jet technology on the comfort and flame retardant properties of cotton woven fabric. Comfort properties have been studied with draping and bending stiffness using Peirce cantilever. Flame resistance was evidenced by exposing the textile fabric to a flame and recording ignition time as well as flame propagation velocity.

\section{MATERIALS AND METHODS}

\section{Material}

The fabric used is plain woven cotton with 57 threads per centimetre in warp and weft. Its surface mass is $123.5 \mathrm{gsm}$. Weft and warp threads are 13.44 Tex and 14.22 Tex respectively.

\section{Atmospheric Pressure Plasma Jet}

Figure 1 illustrates the atmospheric pressure plasma jet technology system from Plasmatreat Company (Plasmatreater AS400) used for the deposition of $\mathrm{SiO}_{x}$ thin films at atmospheric pressure. A high-frequency $(23 \mathrm{kHz})$ pulsed voltage was applied between two tubular electrodes separated by a dielectric material. The PT400 generator delivers a pulsepause modulated current.

The current modulation is controlled by adjusting the plasma cycle time (PCT). With a PCT of $100 \%$, the pulse duration is equal to the pause duration. The main gas flow consists of dry air, which was introduced through the torch at a pressure of 5 Bar. Cotton samples were treated at a moving speed of $10 \mathrm{~m} / \mathrm{min}$ over a surface of $5 \mathrm{~mm}^{2}$ Hexamethyldisiloxane (HMDSO, $\left(\mathrm{CH}_{3}\right)_{3} \mathrm{SiOSi}\left(\mathrm{CH}_{3}\right)_{3}$, purity $98.5 \%$, Sigma-Aldrich) was vaporized at $130{ }^{\circ} \mathrm{C}$, mixed with nitrogen, and introduced into the plasma jet in a downstream region. The flow of the HMDSO was of $20 \mathrm{~g} / \mathrm{h}$ for thin film and of $60 \mathrm{~g} / \mathrm{h}$ for thick coating film. This variation induces a change in the concentration of Siloxane deposited onto the treated surface. The torch can be moved in the $x$ - and $y$-directions, to deposit films over large surfaces, with a typical velocity and substrate to nozzle distance of $5 \mathrm{~m} / \mathrm{min}$ and $30 \mathrm{~mm}$, respectively.

\section{Scanning Electron Microscopy (SEM)}

Scanning Electron Microscope (Model HITACHI TM 3000) was used for morphological characterization of the cotton fibre surface at high magnification. The metallized specimens were analysed in partial vacuum conditions (0.1-0.15 torr), and under an accelerating

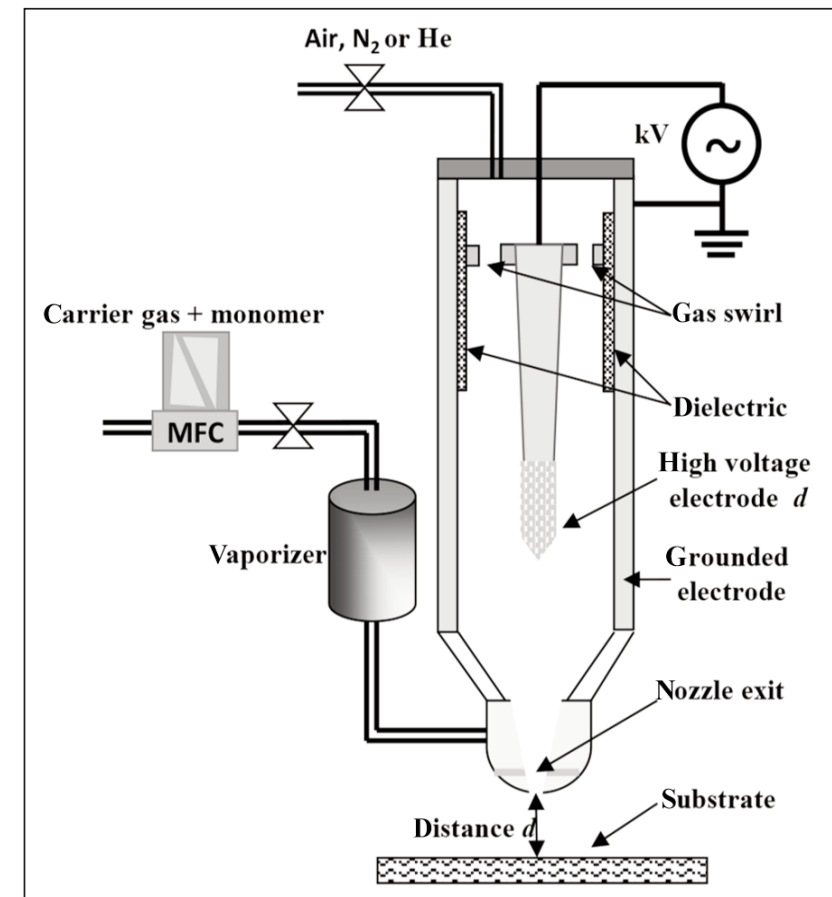

Fig. 1. Atmospheric pressure plasma jet technology system

voltage of $15 \mathrm{KV}$. Scanning Electron Microscopy with Energy Dispersive X-Ray (SEM-EDX) analyses are performed to determine the elementary chemical composition or to present cartography of the distribution of the elements in the form of an image.

\section{Draping}

Standardized tests, according to the French standard of draping NF G 07-109, were performed to determine how a textile fabric fall under its own weight into wavy structures. These structures are quantified objectively to give the draping factor of the fabric. The methods of determining the draping characteristics of a fabric use a circular support on which a circular shaped fabric sample is placed with a protruding section of the support. A ruler is used to record the vertical projection of the contour of the textile specimen falling from the base in 16 positions all around. In our case, the specimen was cut with a diameter of $25 \mathrm{~cm}$ and the support diameter was of $15 \mathrm{~cm}$. The Drape factor, $F$, will then be calculated according to the equation 1 where " $d_{i}$ " is the diameter associated to the projection of the textile vertically on a parallel plan to the circular support of the drape meter:

$$
F=\left(d_{i}^{2}-225\right) / 400
$$

where $i=1$ to $16 . F$ is the comprised between 0 and 1. The more $F$ approaches 0 , the more textile fabric is flexible. $F=0$ corresponds to extremely flexible fabric. $F=1$ corresponds to rigid fabric which does not fall apart the circular support.

This factor also reflects the shear stiffness of a textile material and its comfort when oriented to the clothing industry. 


\section{Bending stiffness}

Standardized (ISO 9073-714005) flexibility tests are performed with the Peirce flexi-meter to determine the bending stiffness of our fabric. In his attempt to evaluate a fabric hand, Peirce introduced the principle of cantilever deformation in textiles to characterize fabric bending [15]. The fabric is made to deform under its own weight and the cantilever length necessary to produce a predetermined deflection angle is measured. As shown in the figure 2, a strip of fabric with well-defined dimensions is moved forward on a horizontal board to project as a cantilever. As soon as the extreme point of the curved fabric touch the inclined board regulated on $41.5^{\circ}$ relative to the horizontal one, the cantilever length $L$ is recorded. This length is then used to calculate the bending length $C$ and the bending rigidity $G$ of the fabric according to equations 2 and 3 :

$$
\begin{gathered}
C=L^{*}(\cos (\alpha / 2) / 8 \operatorname{tang} \alpha)^{(1 / 3)} \sim L / 2 \\
G=w^{*} C^{3}
\end{gathered}
$$

where $w$ is the fabric mass per unit area.

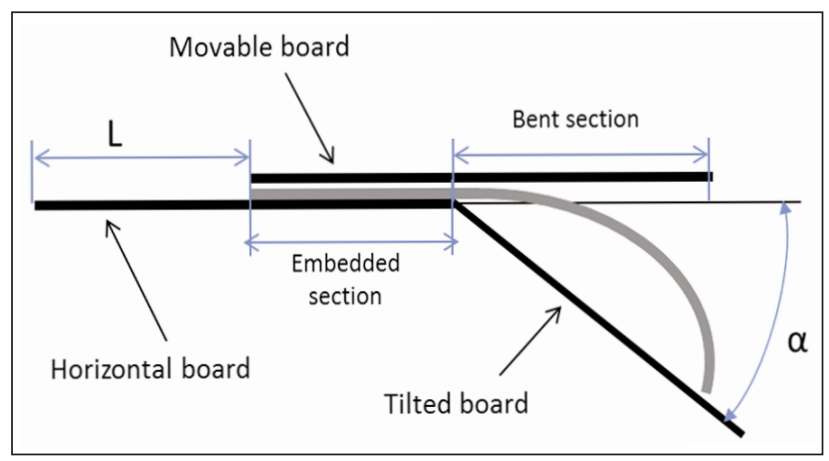

Fig. 2. Peirce cantilever tests for fabrics

\section{Flame propagation}

Tests were performed according to the French standard NF G 07-182 in order to determine the ignition time of the fabric and the flame propagation velocity for fabrics put on $45^{\circ}$ inclined plane. The flame was $40 \mathrm{~mm}$ height, ignited with propane gas and placed perpendicular to the sample holder. The sample has been chosen $200 \mathrm{~mm}$ far from the edge of the entire woven fabric and has dimensions of $160 \mathrm{~mm} \times 600 \mathrm{~mm}$.

\section{RESULTS AND DISCUSSIONS}

\section{Morphology of the coating}

The SEM micrographs show the normal spiral structure of cotton fibre. The untreated surface was found relatively smooth. After flame retardant treatment, the surface of the cotton becomes rougher with the presence of micro particles, which is suggested to be the HMDSO.

EDX analysis shows that they are associated to Siloxane functional groups that represent $35 \%$ of the global surface composition of the fibre in the case of the thick film and $22 \%$ in the case of the thin film. This result is in agreement with previous studies showing that Siloxane is detected on the surface of the coatings elaborated from a solution containing HMDSO. The Si ratio depends on the volumetric ratio of HMDSO [16].

Meanwhile, these microscopic observations on the figure 3 don't give idea whether the treatment penetrated the whole fibres or form a coating to the apparent surfaces exposed to plasma activation. For that reason, the treated cotton fibres sections have been observed under SEM-EDX technique to give composition cartography of the treated fibres section.

Experimentally, when the cotton yarns are cut with scissors or a blade at room temperature, the section at the edge is altered and could not be representative of the whole fibres section within the yarn. To overcome this disadvantage, the fabric has been cut after cooling the whole textile at $-120^{\circ} \mathrm{C}$ with liquid nitrogen then making a sharp fracture that allows maintaining a realistic fibre section. The element $\mathrm{Si}$ has been isolated and represented with the blue colour whereas the fibre components (almost Carbon and Oxygen) with green colour. We observe that the Siloxane coating is concentrated on the external surface of the fibres which are exclusively exposed to the plasma jet.

A simple method was used to confirm the coating formation. The adhesion was evaluated as percent weight add on the samples by substitution in equation 4 :

$$
\text { weight add on }(\%)=100 \frac{W_{t}-W_{0}}{W_{0}}
$$

where $W_{0}$ is initial weight of test sample, and $W_{t}$ - final weight of test sample. Tests were realized following

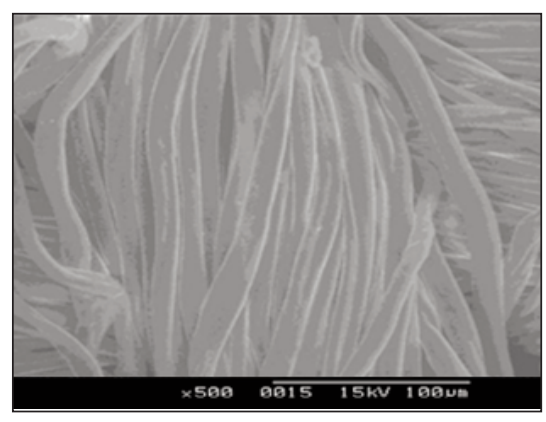

a

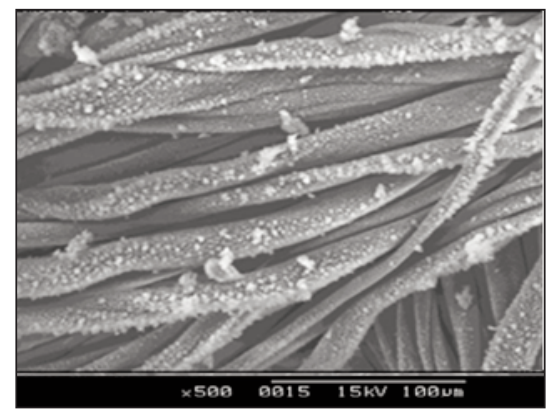

b

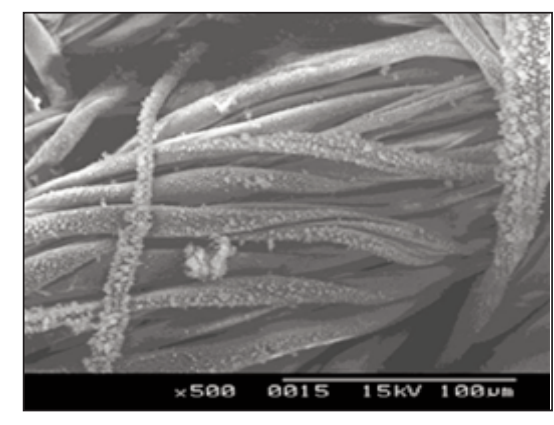

c

Fig. 3. SEM Micrographs associated to: $a$ - non treated cotton fibres; $b$ - treated with plasma deposed HMDSO in thick coating; $c-$ treated with plasma deposed HMDSO in thin coating 


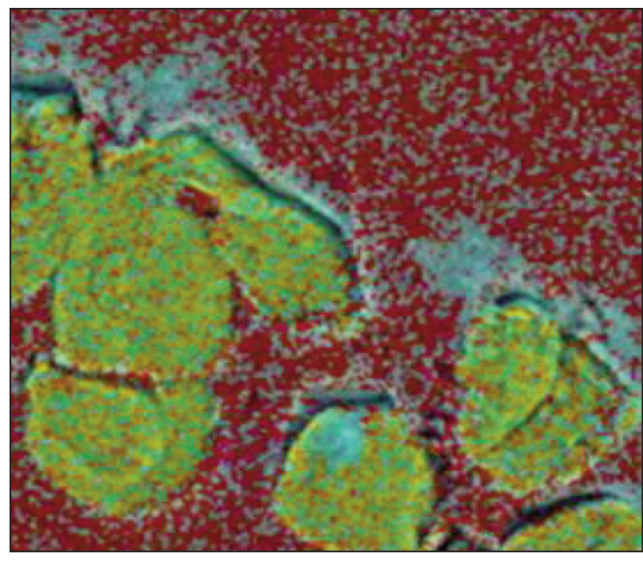

a

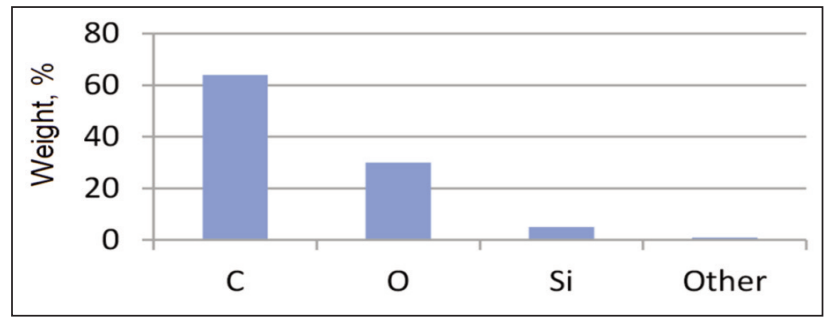

$\boldsymbol{b}$

Fig. 4. Graphical representations of: a - cotton fabric treated with thick plasma coating observed from the section; $b$ - plasma coating's elementary chemical composition

samples preconditioning in a standard atmosphere $\left(20 \pm 2^{\circ} \mathrm{C}, 65 \pm 2 \% \mathrm{RH}\right)$.

Coated cotton (thick coating) showed a weight add on of about $7 \%$. This result reveals that the plasma modification have made the fabric receptive to Siloxane which usually has reduced affinity to cellulosic fibres.

\section{Draping and bending stiffness}

Draping factor increases by $16 \%$ and $21 \%$ for thin and thick coating respectively. Bending under own weight gravity shows the same tendencies for weft and warp yarns. These results prove that the application of Siloxane coating assisted with plasma jet technology is accompanied with an isotropic decrease of the fabric softness (table 1).
Table 1

\begin{tabular}{|c|c|c|c|}
\hline \multicolumn{4}{|c|}{$\begin{array}{c}\text { DRAPING FACTOR AND BENDING RIGIDITY } \\
\text { ASSOCIATED TO THE COTTON FABRIC AT RAW } \\
\text { STATE AND TREATED WITH THICK AND THIN } \\
\text { COATING }\end{array}$} \\
\hline Characteristics & $\begin{array}{l}\text { Raw } \\
\text { cotton }\end{array}$ & $\begin{array}{l}\text { Thin } \\
\text { coating }\end{array}$ & $\begin{array}{l}\text { Thick } \\
\text { coating }\end{array}$ \\
\hline Draping Factor & 0.71 & 0.83 & 0.86 \\
\hline $\begin{array}{l}\text { Weft Bending stiffness } \\
(\mathrm{N} / \mathrm{mm})\end{array}$ & 842 & 966 & 999 \\
\hline $\begin{array}{l}\text { Warp Bending stiffness } \\
(\mathrm{N} / \mathrm{mm})\end{array}$ & 273 & 308 & 315 \\
\hline
\end{tabular}

The important increase in values compared with the control fabric is also attributed to the fact that, during the coating process, only the outer surface of the fibres is treated. This method is often accompanied by excessive weight add on, loss of drape and reduced comfort [17].

As the rigidity of the fabric is generally attributed to the macromolecular structure of fibres coupled with the friction between the fibres $[18,19]$, it could be deduced that the coating enhances the surface fibre friction probably by creating Siloxane bridges between fibres exposed to the plasma jet. This rigidification could not be attributed to the thermal effect induced to the fabric by plasma. In fact, we exposed the fabric to high temperature reaching $105^{\circ} \mathrm{C}$ for 30 minutes without Siloxane deposition and we obtained flexibility and draping factors similar to nontreated cotton.

\section{Resistance to flame}

In this study we are interested to different parameters related to the behaviour of the fabric when exposed to flame. First we investigated the time laps needed to ensure the ignition of the fabric after being in contact with the flame. Then, we investigated the velocity of the flame after ignition. Thereafter, we studied the final structure remaining after ignition being finished. All these data could determine the flame resistance class and orient the final applications associated to the treated textile. Table 2 summarizes the

BEHAVIOUR OF COTTON FABRIC EXPOSED TO FLAME AT RAW STATE, AND TREATED WITH SILOXANE BEFORE AND AFTER WASHING

\begin{tabular}{|c|c|c|c|c|}
\hline Samples & Ignition time (s) & $\begin{array}{c}\text { Flame propagation } \\
\text { velocity }(\mathrm{cm} / \mathrm{s})\end{array}$ & $\begin{array}{c}\text { Surface } \\
\text { remaining (\%) }\end{array}$ & Residue \\
\hline Raw cotton fabric & 0.3 & 1.7 & 0 & ashes \\
\hline Thin Siloxane coating & 1 & 1.1 & 70 & $\begin{array}{l}\text { structure conserved } \\
\text { but carbonized }\end{array}$ \\
\hline Thick Siloxane coating & 1.3 & 0.8 & 85 & $\begin{array}{c}\text { structure conserved } \\
\text { but carbonized }\end{array}$ \\
\hline $\begin{array}{c}\text { Thin Siloxane coating } \\
\text { after washing }\end{array}$ & 1 & 1.1 & 70 & $\begin{array}{l}\text { structure conserved } \\
\text { but carbonized }\end{array}$ \\
\hline $\begin{array}{c}\text { Thick Siloxane coating } \\
\text { after washing }\end{array}$ & 1 & 1.1 & 70 & $\begin{array}{l}\text { structure conserved } \\
\text { but carbonized }\end{array}$ \\
\hline
\end{tabular}


results obtained for the flame resistance performances of the raw and treated cotton fabric.

The resistance to the treatment against domestic washing has been tested according to ISO ISO 6330:2000 [20], procedure 8A (delicate cycle, $30^{\circ} \mathrm{C}$ ) in an automatic washing machine. For the washing process, the sample was stitched onto a piece of ballast.

Compared to the non-treated cotton fabric, Siloxane deposition on the surface improves significantly the textile flame resistance. In fact, the ignition time increases from $0.3 \mathrm{~s}$ to $1 \mathrm{~s}$ for thin coating then to $1.3 \mathrm{~s}$ for thick treatment. Moreover, the velocity of the flame on the fabric after ignition decreases by $35 \%$ and almost to the half for thin and thick coating, respectively. Theses delay in ignition and lowliness in propagation are very important in case of conflagration as it gives more time for rescue and intervention. In another hand, the conservation of the fabric structure after total burning is of high importance especially for house curtains. Actually, in case of fire starting in the curtains, the structure will be maintained and flammable textile will not fall down on carpets which inhibit the propagation of fire in the whole room. After washing, fabric treated with thin coating conserves its properties versus flame exposition whereas the thick coating was not totally permanent to washing and its behaviour becomes similar to that of thin coating fabric. This could be explained by the fact that in thin coating, Siloxane was strongly deposed on the active sites of cotton until saturation of these sites. Thick coating seems to be a superposition of Siloxane films that are not deposed directly on cotton but tethered, with physical affinity, to already deposed film. This physical tethering forms weak bonds which desorbed with washing in only one cycle.

\section{CONCLUSIONS}

Applying Siloxane coating on the cotton fabric surface upgrades the protective properties of the textile to ignition as it postpone the ignition time, slows the propagation of the flame and conserve almost the whole structure of the burned fabric. The application of the Siloxane deposition using plasma technology presents evenly many ecological advantages. In fact, the technology itself is green as it consumes exclusively electrical energy but does not generate wastes that will be ejected in the nature like conventional treatment techniques which need post-industrial waste treatments. The dust generated from the samples facing the plasma is removed using a system that allows the collection and transport of dust particles in a vacuum environment. The particles are charged, floated and collected due to an electrostatic attraction. Moreover, plasma technology could be integrated in already implemented machines as the plasma torch is not bulky and could be hanged between industrial machines or moved using robots. The Siloxane molecules applied are respectful to toxicity guidelines like Reach and RoHS as they do not imply diseases for end-user and within factories. We showed that the Siloxane deposition assisted with plasma jet technology is mainly a surface treatment that does not reach the yarn cores for better flame resistant properties. A thin Siloxane coating film is strongly deposed on the cotton fabric, which conserves its properties after one cycle of domestic washing. Nevertheless, the application of Siloxane with plasma jet technology induces a significant decrease in the fabric softness which could be evidenced with draping and bending stiffness experiments. These draping and bending factors are very important for textile comfort when applied to clothing.

\section{ACKNOWLEDGMENTS}

This work was funded by the Tunisian Ministry of Higher Education and Scientific Research in the framework of the PROJECT 18PJEC12-22.

\section{REFERENCES}

[1] Peng, Y., Cui, Y., Advanced Textiles for Personal Thermal Management and Energy, In: Joule, 2020, 4, 1-19

[2] Keawploy, N., Venkatkarthick, R., Wangyao, P., Zhang, X., Liu, R. , Qin, J., Eco-Friendly Conductive Cotton-Based Textile Electrodes Using Silver- and Carbon-Coated Fabrics for Advanced Flexible Supercapacitors, In: Energy Fuels, 2020, 34, 7, 8977-8986

[3] Scopece, P., Viaro, A., Sulcis, R., Kulyk, I., Patelli, A., Guglielmi, M., Plasma Process, In: Polym., 2009, 6, S705

[4] Chapple, S., Anandjiwala, R., Flammability of Natural Fiber-reinforced Composites and Strategies for Fire Retardancy: A Review, In: Journal of Thermoplastic Composite Materials, 2010, 23, 6, 871-893, https://doi.org/10.1177/0892705709356338

[5] Samanta, K.K., Basak, S., Chattopadhyay, S., Sustainable Flame-Retardant Finishing of Textiles: Advancement in Technology, In: Handbook of Sustainable Apparel Production, CRC Press: Boca Raton, FL, USA, 2015, 64-89

[6] Lu, S.Y., Hamerton, I., Recent developments in the chemistry of halogen-free flame retardant polymers, In: Prog. Polym. Sci. Oxf., 2002, 27, 8, 1661-1712

[7] Khan, F., Characterization of methyl methacrylate grafting onto preirradiated biodegradable lignocellulose fiber by v-radiation, In: Macromol. Biosci., 2005, 5, 1

[8] Ragoubi, M., Bienaimé, D., Molina, S., George, B., Merlin, A., Impact of corona treated hemp fibres onto mechanical properties of polypropylene composites made thereof, In: Industrial Crops Prod., 2010, 31, 2, 344-349 
[9] Baltazar-y-Jimenez, A., Bistritz, M., Schulz, E., Bismarck, A., Atmospheric air pressure plasma treatment of lignocellulosic fibres: impact on mechanical properties and adhesion to cellulose acetate butyrate, In: Compos. Sci. Technol., 2008, 68, 1

[10] Gargoubi, S., Saghrouni, F., Chevallier, P., Tolouei, R., Boudokhane, C., Ladhari, N., Mantovani, D., Polydopaminemodified interface improves the immobilization of natural bioactive-dye onto textile and enhances antifungal activity, In: Biointerphases, 2020, 15, 4, https://doi.org/10.1116/6.0000295

[11] Agnhagea, T., Perwuelz, A., Behary, N., Eco-innovative coloration and surface modification of woven polyester fabric using bio-based materials and plasma technology, In: Industrial Crops and Products, 2016, 86, 334-341

[12] Abd Jelil, R., A review of low-temperature plasma treatment of textile materials, In: Journal of Materials Science, 2015, 50, 5913-5943

[13] Pupytel, J., Kumar, V., Peng, P., Micheli, V., Laidani, N., Arefi-Khonsari, F., Deposition of Organosilicon by a NonEquilibrium Atmospheric Pressure Plasma Jet: Design, Analysis and Macroscopic Scaling Law of the Process, In: Plasma Processes and Polymers, 2011, 8, 664-675

[14] Fridman, A., Kennedy, L.A. (Eds.), Plasma Physics and Engineering, Taylor and Francis, New York, 2004

[15] Peirce, F.T., The "Handle" of Cloth as a Measurable Quantity, In: J. Text. Inst., 1930, 21, T377

[16] Hilt, F., Gherardi, N., Duday, D., Berne, A., Choquet, P., Efficient Flame Retardant Thin Films Synthesized by Atmospheric Pressure PECVD through the High Co-deposition Rate of Hexamethyldisiloxane and Triethylphosphate on Polycarbonate and Polyamide-6 Substrates, In: ACS Applied Materials \& Interfaces, 2016, 8, 12422-12433

[17] Gupta, D., Emerging techniques for functional finishing of textiles, In: Indian Journal of Fibre and Textile Research, 2011, 36, 4, 388

[18] Ghosh, T.K, Zhou, N., Characterizaion of fabric bending behavior: A review of measurement principles, In: Indian Journal of Fibre \& Textile Research, 2003, 28, 471-476

[19] Boisse, P., Hamila, N., Vidal-Sallé, E., Dumont, F., Simulation of wrinkling during textile composite reinforcement forming. Influence of tensile, in-plane shear and bending stiffnesses, In: Composites Science and Technology, Elsevier, 2011, 71, 5, 683

[20] Reifler, F.A., Fortunato, G., Gerhardt, L.-C., Seeger, S., A Simple, One-Step Approach to Durable and Robust Superhydrophobic Textiles, In: Advanced Functional materials, 2008, 18, 3662-3669

\section{Authors:}

\section{RIADH ZOUARI ${ }^{1}$, SONDES GARGOUBI ${ }^{1}$, EMILIA VISILEANU ${ }^{2}$}

${ }^{1}$ Textile Engineering Laboratory - LGTex, University of Monastir, Av Haj Ali Soua, BP68, 5070 Ksar Hellal - Tunisia

${ }^{2}$ The National Research and Development Institute for Textiles and Leather, 16, Lucretiu patrascanu Street, Bucharest, Romania e-mail: e.visileanu@incdtp.ro

\section{Corresponding author:}

RIADH ZOUARI

e-mail: Riadh.Zouari@ksarhelal.r-iset.tn 